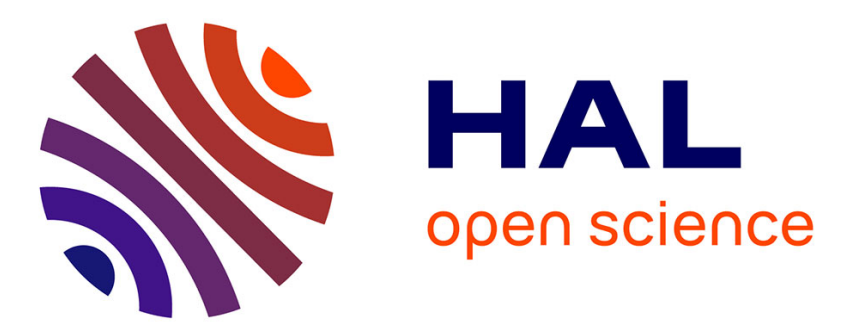

\title{
Long term monitoring of cold-water coral growth shows response to 1 episodic meteorological events in the NW Mediterranean 2
}

Leila Chapron, N. Le Bris, Xavier Durrieu de Madron, Erwan Peru, Pierre E. Galand, Franck Lartaud

\section{To cite this version:}

Leila Chapron, N. Le Bris, Xavier Durrieu de Madron, Erwan Peru, Pierre E. Galand, et al.. Long term monitoring of cold-water coral growth shows response to 1 episodic meteorological events in the NW Mediterranean 2. Deep Sea Research Part I: Oceanographic Research Papers, 2020. hal-02878623

\section{HAL Id: hal-02878623 \\ https://hal.sorbonne-universite.fr/hal-02878623}

Submitted on 23 Jun 2020

HAL is a multi-disciplinary open access archive for the deposit and dissemination of scientific research documents, whether they are published or not. The documents may come from teaching and research institutions in France or abroad, or from public or private research centers.
L'archive ouverte pluridisciplinaire HAL, est destinée au dépôt et à la diffusion de documents scientifiques de niveau recherche, publiés ou non, émanant des établissements d'enseignement et de recherche français ou étrangers, des laboratoires publics ou privés. 

(
Long term monitoring of cold-water coral growth shows response to episodic meteorological events in the NW Mediterranean

Chapron L. ${ }^{1}$, Le Bris N. ${ }^{1}$, Durrieu De Madron X. ${ }^{2}$, Peru E. ${ }^{1}$, Galand P.E. ${ }^{1}$, Lartaud F. ${ }^{1}$

${ }^{1}$ Sorbonne Université, CNRS, Laboratoire d'Ecogéochimie des Environnements Benthiques, LECOB, Observatoire Océanologique, F-66650, Banyuls/Mer, France

${ }^{2}$ CEFREM, CNRS-Université de Perpignan Via Domitia, 52 avenue Paul Alduy, 66860, Perpignan, France.

\section{Abstract}

Lophelia pertusa and Madrepora oculata, two cosmopolitan coral species of the deep ocean, build reef-like structures that provide ecological niches and nurseries for many species. These cold-water corals (CWCs) are thought to grow slowly making associated communities vulnerable to disturbance. However, in situ growth dynamics remains poorly known. The aim of this study was thus to quantify the growth rates of L. pertusa and M. oculata and their variability in relation to environmental conditions that are expected to influence their physiological functions. Such data can be useful to groundtruth physiological rates and improve the prediction of their sensitivity to global change. As part of a long-term monitoring programme of the Lacaze-Duthiers canyon in the Northwestern Mediterranean Sea, fragments of the two species were repeatedly sampled and redeployed at $530 \mathrm{~m}$ depth, from November 2010 to May 2018. Budding rates and linear extensions of L. pertusa and M. oculata were hence quantified and their inter-annual variability documented. The data were analyzed in relation to in situ monitoring of water temperature, current speed and turbidity. 
This study presents the longest in situ survey of the growth patterns of L. pertusa and M. oculata. The observations revealed a strong inter-annual variability in growth rates, both for L. pertusa and M. oculata, and suggest an influence of hydrological conditions on the growth dynamics. Particularly, as regard to episodic water plumes events such as NW wind-induced dense water shelf cascades and E-SE storm-induced downwellings in autumn-winter. In this study, three types of responses were observed: (i) high budding rates but low colony linear extension for strong water plume events periods (ii) low budding rates, low linear extension and high mortality due to high sedimentation rates in the absence of water plumes event, and (iii) high budding rates and high linear extension associated to organic matter supply during medium intensity water plume events. Lophelia pertusa appears to be more resilient to these hydrological changes. Disturbance of the regional circulation patterns, in addition to longer-term change in water mass properties such as warming, deoxygenation and acidification, are thus important parameters to consider for CWC reef stability. This is particularly important since increased storminess, and decreased cascading/downwelling intensities, are predicted to occur within the next century. situ, skeletal growth, dense-water cascading 


\section{Introduction}

52 Engineer species forming three-dimensional structures, such as scleractinian cold-water 53 corals (CWCs), provide ecological niches for a number of associated species (Buhl54 Mortensen et al., 2010). These habitat-building species that support deep-sea 55 biodiversity, have a great ecological value and are listed in the CITES convention 56 (Appendix II) (Foley and Armstrong, 2010). In the last thirty years, significant research 57 efforts by the scientific community have been dedicated to characterize their physiology and ecology, including feeding, reproduction, growth and the associated microbiome (Waller and Tyler, 2005; Roberts, 2009; Lartaud et al., 2014; Lunden et al., 2014; are also observed for M. oculata, another common reef-building species, with growth rates ranging from 0.01 to $18 \mathrm{~mm} \mathrm{y}^{-1}$ (Lartaud et al., 2017). The growth rate variability

Meistertzheim et al., 2016). However, understanding of the CWC ecology still display important knowledge gaps due to the difficulty of studying these species in their natural environment.

Calcification is one of the key physiological indicators of calcifying organism fitness. During the last decades, a number of studies have been dedicated to characterize the growth patterns of CWCs with the aim of establishing adequate conservation strategies (see details in Lartaud et al., in press.). Among all known CWC species, the emblematic Lophelia pertusa exhibits the highest growth rates, but with a high variability, ranging from 0.01 to $38.1 \mathrm{~mm} \mathrm{y}^{-1}$ (Lartaud et al., 2014; 2017). This range contrasts with the growth rate of another deep-sea coral species, Solenosmilia variabilis that exhibits the smallest skeletal growth for scleractinian $\left(\sim 1 \mathrm{~mm} \mathrm{y}^{-1}\right)$ (at $750 \mathrm{~m}$ depth on SW Pacific seamounts observed in Fallon et al., 2014). Differences in growth patterns among studies can be partly explained by the use of different measurement methods, 
such as budding rates analysis, sclerochronology, buoyant weight, alkalinity anomaly or radioisotopic technics. The differences could also be due to the comparison of values originating from different geographic locations, depths, and related environmental conditions (e.g. Gulf of Mexico, Mediterranean Sea, Norway) (Lartaud et al., in press.). Growth rates using the same measurement method for one species like L. pertusa can range from $34 \mathrm{~mm} \mathrm{y}^{-1}$ (the North Sea) to $6 \mathrm{~mm} \mathrm{y}^{-1}$ (Rockall Bank, North Atlantic) (Gass and Roberts, 2006; Wilson, 1979; Lartaud et al., in press). Strong regional variability is also observed like in the Gulf of Mexico where L. pertusa exhibits growth rates varied from $3.8 \mathrm{~mm} \mathrm{y}^{-1}$ (Brooke and Young, 2009) to $32.3 \mathrm{~mm} \mathrm{y}^{-1}$ (Larcom et al., 2014), but for different time period and habitat conditions. Growth rate variability for this coral species was also observed in the Western Mediterranean Sea for different time periods at the same location, with a maximum of $38.1 \mathrm{~mm} \mathrm{y}^{-1}$ (Lartaud et al., 2014; 2017). This limited set of growth rate measurements at different locations using different methods prevents robust assessment of CWC growth patterns in their natural habitat, and highlights the need for longer-term monitoring efforts of growth rates with respect to the local environmental variability.

Experimental studies have led to identify a series of factors that influence the growth patterns of cold water corals. Temperature can influence primary physiological processes like respiration and calcification (Naumann et al., 2014). The seawater pH can also impact these biological parameters (Gori et al., 2016; Hennige et al., 2014). In addition, nutrients, salinity, dissolved oxygen and current speed could affect coral calcification (Cairns and Macintyre, 1992; Thiem et al., 2006; Guinotte et al., 2006 Roberts, 2009; Purser et al., 2010; Lunden et al., 2014). Lartaud et al. (2014) showed through in situ experiments a seasonal difference in growth rates of M. oculata, which was suggested to reflect differences food supplies induced by meteorological events. 
Coral growth rates likely respond differently to the combination of these factors in their

environment. Available data furthermore suggests that CWC growth might be directly modulated by environmental changes. Understanding the growth dynamic of these

103 species, and assessing response to change in habitat conditions, should take into account 104 this variability while defining monitoring strategies.

Understanding the drivers of growth dynamics of CWCs under various

106 environmental conditions is essential to predict their fate in a changing ocean under 107 anthropogenic perturbations (Maier et al., 2012; Hennige et al., 2014; IPCC, 2014; Levin 108 and Le Bris, 2015). In an effort to document the impacts of climate change and other 109 anthropogenic disturbances on a Mediterranean submarine canyon ecosystem hosting 110 abundant colonies of L. pertusa and M. oculata (Gori et al., 2013), we have set up a long111 term in situ monitoring programme focusing on key ecological functions. These 112 functions include coral growth, for which data have been lacking so far on multiannual 113 time-scale. Growth rate can furthermore be used as an assessment tool to determine the 114 health and conservation status of deep-sea reef-building corals in marine protected 115 areas (Davies et al., 2008; Vad et al., 2017; Boolukos et al., 2019).

116 The aim of this study was to investigate the growth patterns of L. pertusa and $M$. 117 oculata over time, to determine their inter-annual temporal dynamics in a region of the 118 Mediterranean where hydrodynamic conditions are seasonally contrasted, with episodic 119 extreme events characterizing winter conditions. These events transporting water 120 masses and particles from the shelf down to the bathyal and abyssal regions vary 121 interannually in frequency and intensity (Béthoux et al., 2002; Canals et al., 2006; 122 Heussner et al., 2006; Durrieu de Madron et al., 2013). The in situ experimental 123 approach implemented to study coral growth was based on yearly deployment and 124 recovery of small coral fragments in a study site located at $530 \mathrm{~m}$ depth in the Lacaze- 
125 Duthiers canyon (LDC), Gulf of Lion, in an area where these two species are naturally 126 abundant. To avoid methodological bias, the growth of L. pertusa and M. oculata was 127 measured using the same method over eight years (as described in Lartaud et al., 2017).

\section{Material and methods}

\subsection{Study site and sampling}

132 The Lacaze-Duthiers submarine canyon, $23 \mathrm{~km}$ long, is located in the northwestern part 133 of the Mediterranean Sea, in the Gulf of Lion. This canyon is located in the Gulf of Lion 134 Marine Nature Park, a Marine Protected Area that harbour abundant populations of 135 CWCs, particularly the stony corals L. pertusa and M. oculata between 300 and $600 \mathrm{~m}$ 136 depth (Fig 1-A-B), which have been explored during the MEDSEACAN cruise of the 137 Marine Protected area agency.

138 Previous publications have described the experimental site for coral growth 139 experiments, called site $\mathrm{A}\left(42^{\circ} 32.43 \mathrm{~N}, 03^{\circ} 25.26 \mathrm{E}\right)$, located at $530 \mathrm{~m}$ depth in the canyon 140 and characterized by large structures of mixed L. pertusa, M. oculata and D. Dianthus 141 (Lartaud et al., 2014, 2017). Coral collections for this study were obtained during eight 142 distinct cruises lead under the LECOB programme 'Biodiversity, extreme environment 143 and global change' ,using the Remotely Operated Vehicle (ROV) Super Achille on the R/V 144 Minibex or the R/V Janus II from COMEX S.A.. Coral samples were expected to belong to 145 the same genetic population considering that they came from the same small area $(<50$ $146 \mathrm{~m}^{2}$ ). Colony fragments of L. pertusa and M. oculata were collected and then transported 147 to the surface using thermally insulated polypropylene boxes that maintain the ambient 148 temperature of deep seawater (i.e., $13^{\circ} \mathrm{C}$ ). On board, the collected corals were 149 transferred into aerated $30 \mathrm{~L}$ seawater tanks maintained at $13^{\circ} \mathrm{C}$ using a chiller. The 
apical part of corals was cut into small nubbins (called NS and corresponding to 5

151 polyps for L. pertusa and 8 polyps for M. oculata) and/or into longer branches (called

152 BS, with $\sim 15$ polyps for L. pertusa and $\sim 20$ polyps for M. oculata). The use of different

153 types of transplant unit (i.e., NS or BS) was previously shown to have no impact on the

154 growth parameters studied (Lartaud et al., 2017). Both types of fragments were glued

155 with an aquatic epoxy resin on transplant units following the protocols described in

156 Lartaud et al (2014) (Fig 1- C). Following years, different deployment conditions were

157 used. First, different nubbins were placed in different orientations on a cobblestone, but 158 no statistical differences were observed in growth rates and polyp mortality between 159 orientations (Lartaud et al., 2014). Also, the deployments on cobblestone directly on the 160 sediment or on a platform about $50 \mathrm{~cm}$ above show no impact on cold water corals 161 growth and mortality (Kruskal-Wallis test, p-value $>0.05$ ).

163 To measure coral growth rates a catch-recapture approach was used during 6 periods of $16412 \pm 2$ months from November 2010 to May 2018 (Table 1). Thirty-seven transplant units 165 were used for L. pertusa, which corresponded to 22 nubbins (NS) and 15 branches (BS). 166 Fifty-one transplants units were used for M. oculata, which corresponded to 32 nubbins 167 and 19 branches. Also, we performed a temporal monitoring of L. pertusa and M. oculata 168 growth rates of the same colonies between 2015 and 2018 to exclude genetic factors.

\subsection{Growth measurements}

171 Each living and dead polyps of the coral nubbins and branches were counted and 172 photographed before and after deployment with the same orientation for comparison.

173 The use of a scale bar on the pictures allows to measure the linear extension of the coral 174 fragments, which corresponds to the calcification between the last polyp observed 
175 before deployment to the summit of the calix of the last polyp observed after recapture.

176 For each year, the maximal linear extension of each BS/NS, which represents the growth

177 capability along a maximum growth direction, were measured using the software ImageJ

178 (Fig 2) (Strömberg et al., 2010; Lartaud et al., 2017). As the growth of L. pertusa and $M$.

179 oculata colonies is driven by the successive addition of new polyps, growing on top of 180 previous generation of polyps, following a longitudinal axis, the addition of new polyps

181 was counted and measured using the protocol established by Lartaud et al. (2014) to

182 determine the budding rates. The budding rate corresponds to the percentage of new 183 polyp added per polyp initially present per year, and thus reflects the density 184 development of polyps within the colony.

185

186

\subsection{Hydrological parameters}

To monitor hydrological parameters of the Lacaze Duthiers canyon, a Nortek Aquadopp single-point acoustic current meter was installed on the experiment platforms from 2015. The probe provided measurements every half hour of the current speed and direction, temperature and acoustic echo intensity in the habitat surrounding the CWCs

191 ( $\sim 530 \mathrm{~m}$ depth in the Lacaze Duthier canyon). Acoustic echo intensity records were 192 converted into suspended particle concentration using an empirical linear equation 193 between the logarithm of concentration (C) and echo intensity (EI) (Gartner, 2004). The 194 equation found using simple regression between concomitant backscatter data and 195 direct sampling concentration in the Gulf of Lions was $10 \times \log \left(\mathrm{C}_{\mathrm{mg} / \mathrm{L}}\right)=0.407 * \mathrm{EI}_{\mathrm{dB}}-$ $19622.55\left(r^{2}=0.94, \mathrm{~N}=66\right)$ (Durrieu de Madron et al., 2017).

197 In addition, significant wave height data series were also used to identify eastern storm 198 periods that generate plateau water export and downwelling in the Lacaze-Duthiers 
canyon (Palanques et al., 2006; Ulses et al., 2008a). They were measured at the Leucate

200 houlograph located about $40 \mathrm{~km}$ northwest to the experimental site.

201 From 2010, in situ temperature was also monitored in the water column of the Lacaze 202 Duthiers at 500 and 1000 m depth using a Nortek Aquadopp single-point acoustic 203 current meter.

204

205

\subsection{Statistical analyses}

206 Statistical analyses were conducted using $\mathrm{R}$ software and tests for normality and 207 homoscedasticity were performed using the Shapiro-Wilk test $(p<0.05)$. Considering 208 that the distribution was not normal for either budding rates, linear extension and 209 mortality, multiple comparison non-parametric tests were used to assess growth 210 differences between years: a Friedman test for the monitoring on the same colony and a 211 multiple Kruskal-Wallis test for the monitoring on different colonies.

\section{Results}

\subsection{Coral survival}

216 There was no significant difference between the survival of the two species (Friedman 217 test, n=11, p<0.05, Fig. 3 and Table S1), with the exception of the period 2017-2018, 218 where M. oculata exhibited higher mortality than L. pertusa (average of $70 \pm 40 \%$ vs 17 $219 \pm 27 \%$ respectively).

220 The mortality of L. pertusa polyps was generally low $(<25 \%)$ except for 20132212014 (100\%), which exhibited significant higher mortalities (K-W test, $n=37, p<0.05$, 222 Table S1). Also, there was a high mortality observed for L. pertusa polyps for 2015-2016 
223 (71 $\pm 46 \%)$, which was significantly different from 2010-2011 (0\%) and 2017-2018 (17

$224 \pm 27 \%)(K-W$ test, $n=37, \mathrm{p}<0.05$, Table $\mathrm{S} 1)$.

For M. oculata, the percentages of dead polyps were more variables. As for $L$. pertusa, the lowest value observed was for 2010-2011 (0\%) and the highest for 20132014 (98 $\pm 11 \%$ ), which were statistically different compared to the other periods (K-W test, $\mathrm{n}=51, \mathrm{p}<0.05$, Table S1). The periods 2015-2016 (71 $\pm 35 \%)$ and 2017-2018 (70 \pm $40 \%)$ were also characterized by high polyp mortality.

\subsection{Budding rates}

232

There was no statistical difference in budding rates between L. pertusa and M. oculata except for the 2016-2017 and 2017-2018 periods, with significantly higher values for $L$. pertusa (Friedman test, n=11, p<0.05, Fig. 4 and Table S2). excepted for 2013-2014 (1 $\pm 3 \%$ ) and 2015-2016 (22 $\pm 34 \%)$. Specifically, budding rates for 2013-2014 were statistically lower compared to the other periods (K-W test, $\mathrm{n}=37, \mathrm{p}<0.05$, Table S2).

For M. oculata, the budding rates were variable with significantly higher rates observed in 2010-2011 (54 $\pm 22 \%$ ) and 2016-2017 (28 $\pm 17 \%)$. For the other time

241 periods, the mean budding rates were below $25 \%$.

\subsection{Linear extension}

244 There was no statistical difference between L. pertusa and M. oculata for the linear 245 extensions except for the 2016-2017 and 2017-2018 periods, with significantly higher growth rates for L. pertusa (Friedman test, n=11, p<0.05, Fig. 5 and Table S3). 
The mean linear extensions of L. pertusa were significantly higher during 2016$2017\left(24 \pm 7 \mathrm{~mm} \mathrm{y}^{-1}\right)$ and 2017-2018 (26 $\left.\pm 9 \mathrm{~mm} \mathrm{y}^{-1}\right)$ compared to the other periods 249 (mean values ranging from 1 to $5 \mathrm{~mm} \mathrm{y}^{-1}$ ) ( $\mathrm{K}-\mathrm{W}$ test, $\mathrm{n}=88, \mathrm{p}<0.05$, Table S3). The 250 highest values were recorded for coral fragments deployed during the 2016-2017 251 period $\left(40.2 \mathrm{~mm} \mathrm{y}^{-1}\right)$.

For $M$. oculata, the average linear extension was low $\left(\leq 4 \mathrm{~mm}^{-1}\right)$ except for 2016-2017, which displayed a significantly higher growth rate $\left(9 \pm 6 \mathrm{~mm} \cdot \mathrm{y}^{-1}\right)$.

The monitoring of temperature, current and suspended particles matter (SPM) 257 concentration conducted at $530 \mathrm{~m}$ depth in the Lacaze Duthiers canyon revealed a significant seasonal and interannual variation of the bottom hydrological and current conditions in the canyon head (Fig. 6). First, these parameters were stable during most 260 of the year except during winter (January-March), which exhibited a period 261 characterized by intermittent temperature drops concurrent with increases in current 262 speed and SPM concentration.

263 The bottom currents during these episodes are directed down-canyon. In 2016-2017 264 (Fig. 6-B) and 2017-2018 (Fig 6-C), these episodic signals are often concomitant with 265 high significant wave heights $(>2-3 \mathrm{~m})$ recorded at the coast. They are therefore the 266 signature of a water export from the continental shelf to the head of the canyon linked to 267 downwellings induced by easterly winds (as shown by Palanques et al., 2006 and Ulses 268 et al., 2008a). The lower temperature of the shelf waters compared to the slope waters 269 resulted from the formation of cold and dense water along the coast, which can be 270 rapidly exported to the slope during this eastern storms (as observed in winter 2013, 271 Fig S1) (Ulses et al., 2008b). However, some episodes such as those in March 2015 and 
January 2018 (Fig. 6-A and C) also indicate that there are periods of export and dense

273 shelf water cascading in the canyon independently of these eastern storms. This export

274 is possible under the effect of strong northward winds that are at the origin of the

275 formation by evaporation of cold and dense water at the coast (as observed in winter

276 2012, Fig S1) (Ulses et al., 2008c).

277 In all cases, the increase in SPM concentration could result both from the bottom

278 transport of fine sediment from the shelf and from the local resuspension of sediment in

279 the canyon head. The intensity of the currents during these brief events, between 20 and

$28070 \mathrm{~cm} / \mathrm{s}$ is sufficient to erode and resuspend fine (clayey and silty) sediments.

\section{Discussion}

283

4.1. Interannual variation in the growth of Lophelia pertusa

The growth patterns of L. pertusa (linear extension and rate of new polyp addition) varied between years. Based on the monitored parameters (mortality, budding rate and

287 linear extension), three main response type can be described for L. pertusa: (i) high 288 budding rate but low linear extension (2010-2011 and 2011-2012), (ii) low budding 289 rate, low linear extension and high mortality (2013-2014 and 2015-2016), and (iii) high 290 budding rate and high linear extension (2016-2017 and 2017-2018). Since the corals 291 were deployed at the same location, their growth responses are likely primarily 292 controlled by the surrounding environmental conditions. Particularly for the periods of 293 survey of the same colonies.

294 In the Mediterranean Sea, CWCs are found in submarine canyons where the 295 environmental conditions can vary between years because of episodic dense shelf water 296 events (Canals et al., 2006). Three different types of water plumes are described, 
corresponding to autumnal storm events (stratified water masses with low intensity), winter storm events (large amount of particles) and winter cascading events (nonstratified water masses with high intensity) (Canals et al., 2006). These events lead to ventilation, changes in the temperature, current speed and transport of material such as 301 organic matter and sediments (Canals et al., 2006; Bonnin et al., 2008; Durrieu de Madron et al., 2013). The input in organic matter is essential to CWCs that are considered to feed primarily on zooplankton and phytodetritus with a preference for 304 living food (Houlbrèque et al., 2004; Kiriakoulakis et al., 2005; Duineveld et al., 2007; 305 Becker et al., 2009; Purser et al., 2010; Tsounis et al., 2010). The change in intensity of these events from year to year, strongly associated with the local meteorological 307 conditions at the surface (Heussner et al., 2006), should impact the growth of L. pertusa. The periods 2013-2014 and 2015-2016 (Fig. S1) showed the lowest budding rates and linear extensions combined with the highest L. pertusa mortality. The present and earlier in situ observations (Lartaud et al., 2017) revealed a high sedimentation rate

311 during these periods, which led to the partial burial of the coral colonies deployed.

312 Sediment exposure leads to physical abrasions of the coral tissues and to a depletion in 313 oxygen for the polyps (Larsson and Purser, 2011). Moreover, the accumulation of 314 sediment particles on the tissues (e.g. coenosarc) can limit food access for the polyps. 315 Sediment cleaning by tentacle movements, tissue distension and mucus secretion also 316 has an energy cost for the coral (Rogers, 1999). Even though moderate concentrations of 317 suspended particles used as nutritional sources can be beneficial, a high sediment 318 concentration leads to coral mortality (Mortensen, 2001). The corals' energy budget are 319 altered by sediment particles that lead to a higher metabolic activity (represented by 320 respiration rates) (Larsson et al., 2013). It has also been reported that stress induced by 321 sediment particles limits the tissues and skeleton growth of scleractinian corals 
(Anthony et al., 2002). Thus, in a highly turbid environment, the CWCs need to maintain their essential physiological functions (e.g. respiration, remove particles) by allocating their energy away from secondary functions such as biomineralization. In contrast, the periods 2016-2017 and 2017-2018 showed the highest budding rates and linear extension with low mortalities for L. pertusa. In situ observations showed low sedimentation coupled with winter storm events with comparable moderate intensities for both periods (Fig. 6). Laboratory studies suggest that the increase in food supply, rather than temperature, may control growth rates of CWCs (Mortensen, 2001; Roberts and Anderson, 2002; Orejas et al., 2011b). A reduction in food supply caused a significant decline in the calcification of CWCs (Naumann et al., 2011). Thus, the rapid transport of fresh and labile organic matter during downwelling and cascading events observed during these periods may promote physiological processes, as biomineralization, which is directly positively linked to their ability to catch suspended prey from the water column (van Oevelen et al., 2009). Optimal growth conditions for L. pertusa in the Lacaze Duthiers canyon are thus suggested to be strongly influenced by the occurrence of dense shelf water cascades or storm-induced downwelling as suggested (Lartaud et al., 2014), a major driver being the prevention of excessive sedimentation on coral surfaces.

However, strong hydrological events can reduce growth patterns as observed for the 2010-2011 and 2011-2012 periods. The combination of a high addition of new polyps together with low linear extension observed for L. pertusa suggests that the energy budget was allocated to the production of small polyps and not to the linear growth of the colony. This process may thicken the colony that will better resist to strong water current. It could promote an increase in number of polyp mouths to catch and ingest more food resources from the water column (Musco et al., 2018). Contrary to 
2016-2017 and 2017-2018, the 2010-2011 and 2011-2012 episodic water plumes were characterized by stronger intensities. The winter 2012 exhibited one of the strongest cascade event recorded in the Gulf of Lion (Durrieu de Madron et al., 2013, Fig S1), and several strong winter storms in the Lacaze Duthiers canyon occurred in 2011 (Puig et al.,

351 2013, Fig S1). Thus, the optimal growth for L. pertusa in the Lacaze Duthiers canyon seems to be favored by episodic winter downwelling events of moderate intensity. It shows that cascading events can have antagonist effects on CWCs with the positive effect

354 of food supply in one hand, and on the other hand, the negative effect of currents that 355 are too strong to allow cold water coral polyps to catch preys (Pusceddu et al., 2013; 356 Orejas et al., 2016). This argument should, however, be considered with caution as the 357 importance of these events, lasting only a few weeks, in the annual nutritional budget of 358 corals that is still poorly known.

\subsection{Interannual variation in the growth of Madrepora oculata}

361 Madrepora oculata also displayed high variability in the growth patterns between years.

362 The growth responses scenarios were: (i) high budding rates but low linear extension 363 (2010-2011), (ii) low budding rates, low linear extension and high mortality (2011364 2012, 2013-2014, 2015-2016 and 2017-2018) and (iii) high budding rates and high 365 linear extension (2016-2017). The scenario (ii) appeared more frequently for M. oculata than L. pertusa. As for $L$. 367 pertusa, the unfavorable growth conditions in 2013-2014 and 2015-2016 might 368 correspond to high sediment concentrations in the coral habitat. It has been shown that 369 sediment cover must be considered as a fundamental limiting factor for various CWC 370 species, and could be considered to describe the health status of deep-water coral reefs 371 (Lartaud et al., 2017). The period 2011-2012, associated to a strong cascading event 
during winter 2012 (Durrieu de Madron et al., 2013, Fig S1), suggests that M. oculata is more sensitive to strong currents than L. pertusa. The high current velocities associated with cascading events may not be optimal for $M$. oculata prey capture rates, or the energy budget may not be sufficient to allow biomineralization under these environmental conditions. However, in the 2017-2018 period that was characterized by an episode of dense water plumes of moderate intensity, both the linear extension and budding rates remain low. Thus, M. oculata appear to be more sensitive than L. pertusa to environmental variations.

The scenario (i) for M. oculata follows the same pattern as for L. pertusa for 20102011 characterized by an intense winter storm (Puig et al., 2013, Fig S1). It suggests that high intensity hydrological events may have a negative impact on $M$. oculata biomineralization, although this species, similarly to L. pertusa, can display an increase in polyp density rather than the colony extension as a response to such events. In opposition, the optimal growth rates observed for M. oculata were in 2016-2017, which was characterized by a moderate winter storm (Fig. 6). Thus, the scenario (iii) should represent median to favorable environmental conditions for this species. Moreover, the difference between 2016-2017 and 2017-2018 are characterized by hydrological events of similar intensities but not occurring at the same period of the year (Fig. 6). The export of nutrients from surface waters to deeper water layers in the canyon are likely different in both quantity and quality considering the seasonality in phytoplankton blooms in late winter to early spring (Heussner et al., 2006).

\subsection{Distinct responses of L. pertusa and M. oculata to environmental conditions} It was previously shown that L. pertusa has a higher growth rate than M. oculata (Lartaud et al., 2014; 2017), particularly at the studied location in the Lacaze-Duthiers 
canyon where L. pertusa dominates the assemblages (Gori et al., 2013; Fabri et al., 2014).

398 This study highlights the different growth dynamics between the two species in 399 response to local environment within a shared habitat. Both species feed primarily on 400 zooplankton and phytodetritus (Duineveld et al., 2007; Carlier et al., 2009). Lophelia 401 pertusa is, however, a more opportunistic feeder (Dodds et al., 2009) and has a higher 402 prey capture rate (Kiriakoulakis et al., 2005; Tsounis et al., 2010). As a consequence, $L$.

403 pertusa should be less impacted by changes in food type, likely associated to the 404 intensity and period of occurrence of water plumes. Other factors such as the 405 reproduction strategy (Waller and Tyler, 2005) and the microbiome (Meistertzheim et al., 2016) suggest more plasticity in the behavior of L. pertusa and could partly explain a 407 higher resilience to environmental changes compared to M. oculata. In the NE Atlantic 408 Ocean, L. pertusa's seasonal reproductive strategy involves the spawning of a high 409 quantity of small oocytes for a maximal dispersion, contrary to M. oculata that spawns a 410 smaller quantity of bigger oocytes. This suggests that $M$. oculata may produce and 411 spawn gametes only during optimal conditions for reproduction (Waller and Tyler, 412 2005). In addition, M. oculata is more sensitive to thermal stress compared to L. pertusa 413 (Naumann et al., 2014; Brooke et al., 2013) which suggests that L. pertusa is more plastic 414 in term of temperature variations. At the level of the microbiome, the difference in 415 associated bacterial community composition could also reflect different ecological 416 strategies. Madrepora oculata has a very specific microbiome in contrast with the more 417 versatile microbiome for L. pertusa, suggesting again that this species is more plastic to 418 environmental variations (Meistertzheim et al., 2016).

It is thus essential to incorporate the inter species responses to forecast future changes of deep sea reefs and establish efficient conservation measures for these critical

421 habitats, particularly considering that CWCs are at their upper thermal tolerance in the 
422

423

424

425

426

427

428

429

430

431

432

433

434

435

436

437

438

439

440

441

442

443

444 445

Mediterranean region (Freiwald et al., 2004). In this region, predictive models using the IPCC A2 scenario indicate less precipitation and river runoff in the coming century, with higher temperatures suggesting that dense water shelf cascade to the deep basin in the Gulf of Lion could disappear by 2100 (Somot et al., 2006; Herrmann et al., 2008).

\subsection{Are cold-water corals slow-growing species?}

Scleractinian cold-water corals have long been considered as slow-growing species with growth rates below $1 \mathrm{~cm} \mathrm{y}^{-1}$ (Wilson, 1979; Freiwald and Roberts, 2006), much lower than zooxanthellate scleractinian coral growth that can exceed $15 \mathrm{~cm} \mathrm{y}^{-1}$ for some species (Dullo, 2005). This study highlights that in situ CWCs biomineralization can be much higher and comparable to some of their shallow water analogues. Some studies already showed that scleractinian cold water corals could exceed $3 \mathrm{~cm} \mathrm{y}^{-1}$ in the Mediterranean Sea and the Gulf of Mexico (Lartaud et al., 2017; Larcom et al., 2014), but here we report growth rates reaching $4 \mathrm{~cm} \mathrm{y}^{-1}$. The growth of CWCs is strongly influenced by biotic and abiotic factors such as food supply, hydrography and temperature (Cairns and Macintyre, 1992; Thiem et al., 2006; Guinotte et al., 2006; Roberts, 2009; Purser et al., 2010). Temperature increase can improve physiological processes such as growth rates due to increase metabolism efficiency (Dodds et al., 2007). However, the thermal optimum and the potential for adaptation to temperature variations are still unknown for CWCs. Although in the Mediterranean Sea, CWCs are thought to reach their upper ecological thermic limit (i.e., $14^{\circ} \mathrm{C}$ ) (Freiwald et al., 2004), the high growth rates could reflect present particular favorable conditions compared to other coral areas, likely due to the supply of food from peculiar hydrological conditions.

\section{Conclusion}


447 This first long-term in situ study conducted on CWCs highlights growth rate variations 448 associated with inter-annual changes in environmental conditions driven by

449 hydrological processes. In the Lacaze Duthiers canyon, episodic hydrologic events (e.g. 450 downwelling, cascading, storms) transport surface waters drive organic particles from 451 surface production inside the canyon and are likely to modulate the quality and quantity 452 of food available for CWCs. Consistent with these irregular inputs, the growth of CWCs 453 differs from year to year depending on the type of dense water shelf event: (i) strong 454 water plume events cause high budding rates but low colony linear extension by limiting 455 prey capture rates with high current speed, (ii) the absence of water plume events cause 456 low budding rates, low linear extension and high mortality due to high sedimentation 457 rates, and (iii) median water plume events cause high budding rates and high linear 458 extension associated with higher organic matter supply. Furthermore, we observed an 459 inter-specific variability in mortality, growth rates and linear extension between $L$. 460 pertusa and $M$. oculata. Lophelia pertusa appears more plastic to environmental 461 variation as compared to M. oculata. Finally, we demonstrated for the first time that $L$. 462 pertusa could reach linear extension comparable to their shallow water counterparts. In the context of the ongoing global change, an increase of the stratification is 464 expected in the Mediterranean Sea, which will reduce the supply of fresh oxygenated 465 water containing organic matter from the surface to the deep ocean. The resilience of 466 cold-water corals in the future Mediterranean Sea is threated, particularly considering 467 that CWCs are supposed at their upper thermal tolerance. It is essential to incorporate 468 the inter species responses to establish efficient conservation strategies for these critical 469 habitats. 
LC, FL, NLB and PG designed the study. LC, NLB, XDDM, EP, PG and FL conducted the study, analyzed the data and wrote the paper.

474

475 Funding

476 This work was funded by the chair 'Extreme environment, biodiversity and global 477 change' supported by Fondation TOTAL, UPMC and CNRS. We thank the crew of the RV 478 'Minibex' and Janus II (COMEX) for their assistance in fieldwork. LC's PhD grant was 479 funded by the French Ministry of Higher Education, Research and Innovation through 480 the Doctoral School 'Sciences de l'Environnement d'Ile de France - ED129'. This study used results from the national CANDHIS in situ wave measurement database.

\section{Additional information}

484

Supplementary information accompanies this paper.

Competing Interests: The authors declare no competing interests.

Figure and table captions

Figure 1: Cold-water coral reefs with (A) Lophelia pertusa, and (B) Madrepora oculata in the Lacaze-Duthiers canyon (C) where branches and nubbins has been deployed on transplant units fixed to a deep-sea experimentation platform (C) UPMC-Fondation TOTAL).

494 Figure 2: The pictures represent the same replicate of L. pertusa during four years (in 495 purple, the first linear extension during 2015-2016, the second in green during 20164962017 and the third in red during 2017-2018). 
Figure 3: Polyp mortality of L. pertusa (grey) and M. oculata (white bars) between 2010 and 2018. All the values represented the median and quartiles.

501 Figure 4: Budding rates (\%) of L. pertusa (grey) and M. oculata (white bars) between 2010 and 2018. All the values represented the median and quartiles.

504 Figure 5: Linear extension (mm.y ${ }^{-1}$ ) of L. pertusa (grey) and M. oculata (white bars) 505 between 2010 and 2018. All the values represented the median and quartiles.

506

Figure 6: Time series of significant wave height at the Leucate site, near-bottom temperature, near-bottom current speed component along the canyon axis, and nearbottom suspended particle matter concentration, at $530 \mathrm{~m}$ depth in the Lacaze-Duthiers canyon for the (A) 2015-2016, (B) 2016-2017 and (C) 2017-2018.

512 Table 1: Characteristics of the transplant units used for each time period for L. pertusa 513 and M. oculata. The mean \pm SD is shown for the polyp mortality.

\section{$515 \quad$ References}

516 Anthony, K.R.N., Connolly, S.R., Willis, B.L., 2002. Comparative analysis of energy 517 allocation to tissue and skeletal growth in corals. Limnology and Oceanography 47, 1417518 1429. https://doi.org/10.4319/lo.2002.47.5.1417

519 Becker, E.L., Cordes, E.E., Macko, S.A., Fisher, C.R., 2009. Importance of seep primary 520 production to Lophelia pertusa and associated fauna in the Gulf of Mexico. Deep Sea 521 Research Part I: Oceanographic Research Papers 56, 786-800. 
https://doi.org/10.1016/j.dsr.2008.12.006

523 Béthoux, J.P., De Madron, X.D., Nyffeler, F., Tailliez, D., 2002. Deep water in the western

524 Mediterranean: peculiar 1999 and 2000 characteristics, shelf formation hypothesis, variability 525 since 1970 and geochemical inferences. Journal of Marine Systems 33, 117-131.

526 Bonnin, J., Heussner, S., Calafat, A., Fabres, J., Palanques, A., Durrieu de Madron, X., Canals, 527 M., Puig, P., Avril, J., Delsaut, N., 2008. Comparison of horizontal and downward particle 528 fluxes across canyons of the Gulf of Lions (NW Mediterranean): Meteorological and 529 hydrodynamical forcing. Continental Shelf Research 28, 1957-1970. 530 https://doi.org/10.1016/j.csr.2008.06.004

531 Boolukos, C.M., Lim, A., O’Riordan, R.M., Wheeler, A.J., 2019. Cold-water corals in decline 532 - A temporal (4 year) species abundance and biodiversity appraisal of complete 533 photomosaiced cold-water coral reef on the Irish Margin. Deep Sea Research Part I: 534 Oceanographic Research Papers 146, 44-54. https://doi.org/10.1016/j.dsr.2019.03.004

535 Brooke, S., Ross, S.W., Bane, J.M., Seim, H.E., Young, C.M., 2013. Temperature tolerance 536 of the deep-sea coral Lophelia pertusa from the southeastern United States. Deep Sea 537 Research Part II: Topical Studies in Oceanography 92, 240-248. 538 https://doi.org/10.1016/j.dsr2.2012.12.001

539 Brooke, S., Young, C., 2009. In situ measurement of survival and growth of Lophelia pertusa 540 in the northern Gulf of Mexico. Marine Ecology Progress Series 397, 153-161. 541 https://doi.org/10.3354/meps08344

542 Buhl-Mortensen, L., Vanreusel, A., Gooday, A.J., Levin, L.A., Priede, I.G., Buhl-Mortensen, 543 P., Gheerardyn, H., King, N.J., Raes, M., 2010. Biological structures as a source of habitat 544 heterogeneity and biodiversity on the deep ocean margins: Biological structures and 545 biodiversity. Marine Ecology 31, 21-50. https://doi.org/10.1111/j.1439-0485.2010.00359.x

546 Cairns, S.D., Macintyre, I.G., 1992. Phylogenetic implications of calcium carbonate 
547 mineralogy in the Stylasteridae (Cnidaria: Hydrozoa). PALAIOS 7, 96.

548 https://doi.org/10.2307/3514799

549 Canals, M., Puig, P., de Madron, X.D., Heussner, S., Palanques, A., Fabres, J., 2006. Flushing

550 submarine canyons. Nature 444, 354-357. https://doi.org/10.1038/nature05271

551 Carlier, A., Le Guilloux, E., Olu, K., Sarrazin, J., Mastrototaro, F., Taviani, M., Clavier, J., 552 2009. Trophic relationships in a deep Mediterranean cold-water coral bank (Santa Maria di 553 Leuca, Ionian Sea). Marine Ecology Progress Series 397, 125-137. 554 https://doi.org/10.3354/meps08361

555 Davies, A.J., Wisshak, M., Orr, J.C., Murray Roberts, J., 2008. Predicting suitable habitat for 556 the cold-water coral Lophelia pertusa (Scleractinia). Deep Sea Research Part I:

557 Oceanographic Research Papers 55, 1048-1062. https://doi.org/10.1016/j.dsr.2008.04.010

558 Dodds, L., Black, K., Orr, H., Roberts, J., 2009. Lipid biomarkers reveal geographical 559 differences in food supply to the cold-water coral Lophelia pertusa (Scleractinia). Marine 560 Ecology Progress Series 397, 113-124. https://doi.org/10.3354/meps08143

561 Dodds, L.A., Roberts, J.M., Taylor, A.C., Marubini, F., 2007. Metabolic tolerance of the cold562 water coral Lophelia pertusa (Scleractinia) to temperature and dissolved oxygen change. 563 Journal of Experimental Marine Biology and Ecology 349, 205-214. 564 https://doi.org/10.1016/j.jembe.2007.05.013

565 Duineveld, G.C., Lavaleye, M.S., Bergman, M.J., De Stigter, H., Mienis, F., 2007. Trophic 566 structure of a cold-water coral mound community (Rockall Bank, NE Atlantic) in relation to 567 the near-bottom particle supply and current regime. Bulletin of Marine Science 81, 449-467.

568 Dullo, W.-C., 2005. Coral growth and reef growth: a brief review. Facies 51, 33-48. 569 https://doi.org/10.1007/s10347-005-0060-y

570 Durrieu de Madron, X., Houpert, L., Puig, P., Sanchez-Vidal, A., Testor, P., Bosse, A., 571 Estournel, C., Somot, S., Bourrin, F., Bouin, M.N., Beauverger, M., Beguery, L., Calafat, A., 
572 Canals, M., Cassou, C., Coppola, L., Dausse, D., D’Ortenzio, F., Font, J., Heussner, S.,

573 Kunesch, S., Lefevre, D., Le Goff, H., Martín, J., Mortier, L., Palanques, A., Raimbault, P., 574 2013. Interaction of dense shelf water cascading and open-sea convection in the northwestern

575 Mediterranean during winter 2012: Shelf cascading and open-sea convection. Geophysical 576 Research Letters 40, 1379-1385. https://doi.org/10.1002/grl.50331

577 Durrieu de Madron, X., Ramondenc, S., Berline, L., Houpert, L., Bosse, A., Martini, S., Guidi, 578 L., Conan, P., Curtil, C., Delsaut, N., Kunesch, S., Ghiglione, J.F., Marsaleix, P., Pujo-Pay, 579 M., Séverin, T., Testor, P., Tamburini, C., the ANTARES collaboration, 2017. Deep sediment 580 resuspension and thick nepheloid layer generation by open-ocean convection: BNL generation 581 by open-ocean convection. Journal of Geophysical Research: Oceans 122, 2291-2318. 582 https://doi.org/10.1002/2016JC012062

583 Fabri, M.-C., Pedel, L., Beuck, L., Galgani, F., Hebbeln, D., Freiwald, A., 2014. Megafauna 584 of vulnerable marine ecosystems in French mediterranean submarine canyons: Spatial 585 distribution and anthropogenic impacts. Deep Sea Research Part II: Topical Studies in 586 Oceanography 104, 184-207. https://doi.org/10.1016/j.dsr2.2013.06.016

587 Fallon, S.J., Thresher, R.E., Adkins, J., 2014. Age and growth of the cold-water scleractinian 588 Solenosmilia variabilis and its reef on SW Pacific seamounts. Coral Reefs 33, 31-38. 589 https://doi.org/10.1007/s00338-013-1097-y

590 Foley, N., Armstrong, C.W., 2010. The ecological and economic value of cold-water coral 591 ecosystems.

592 Freiwald, A., Fossa, J.H., Grehan, A., Koslow, T., Roberts, J.M., 2004. Cold water coral 593 reefs: out of sight-no longer out of mind.

594 Freiwald, A., Roberts, J.M., 2006. Cold-water corals and ecosystems. Springer Science \& 595 Business Media.

596 Gartner, J.W., 2004. Estimating suspended solids concentrations from backscatter intensity 
measured by acoustic Doppler current profiler in San Francisco Bay, California. Marine

598 Geology 211, 169-187. https://doi.org/10.1016/j.margeo.2004.07.001

599 Gass, S.E., Roberts, J.M., 2006. The occurrence of the cold-water coral Lophelia pertusa

600 (Scleractinia) on oil and gas platforms in the North Sea: Colony growth, recruitment and

601 environmental controls on distribution. Marine Pollution Bulletin 52, 549-559.

602 https://doi.org/10.1016/j.marpolbul.2005.10.002

603 Gori, A., Ferrier-Pagès, C., Hennige, S.J., Murray, F., Rottier, C., Wicks, L.C., Roberts, J.M., 604 2016. Physiological response of the cold-water coral Desmophyllum dianthus to thermal stress 605 and ocean acidification. PeerJ 4, e1606. https://doi.org/10.7717/peerj.1606

606 Gori, A., Orejas, C., Madurell, T., Bramanti, L., Martins, M., Quintanilla, E., Marti-Puig, P., 607 Lo Iacono, C., Puig, P., Requena, S., Greenacre, M., Gili, J.M., 2013. Bathymetrical 608 distribution and size structure of cold-water coral populations in the Cap de Creus and 609 Lacaze-Duthiers canyons (northwestern Mediterranean). Biogeosciences 10, 2049-2060. 610 https://doi.org/10.5194/bg-10-2049-2013

611 Guinotte, J.M., Orr, J., Cairns, S., Freiwald, A., Morgan, L., George, R., 2006. Will human612 induced changes in seawater chemistry alter the distribution of deep-sea scleractinian corals? 613 Frontiers in Ecology and the Environment 4, 141-146. https://doi.org/10.1890/1540614 9295(2006)004[0141:WHCISC]2.0.CO;2

615 Hennige, S.J., Wicks, L.C., Kamenos, N.A., Bakker, D.C.E., Findlay, H.S., Dumousseaud, C., 616 Roberts, J.M., 2014. Short-term metabolic and growth responses of the cold-water coral 617 Lophelia pertusa to ocean acidification. Deep Sea Research Part II: Topical Studies in 618 Oceanography 99, 27-35. https://doi.org/10.1016/j.dsr2.2013.07.005

619 Herrmann, M., Estournel, C., Déqué, M., Marsaleix, P., Sevault, F., Somot, S., 2008. Dense 620 water formation in the Gulf of Lions shelf: Impact of atmospheric interannual variability and 621 climate change. Continental Shelf Research 28, 2092-2112. 
622

623

624

625

626

627

628

629

630

631

632

633

634

635

636

637

638

639

640

641 Larsson, A.I., Purser, A., 2011. Sedimentation on the cold-water coral Lophelia pertusa:

642 Cleaning efficiency from natural sediments and drill cuttings. Marine Pollution Bulletin 62,

643 1159-1168. https://doi.org/10.1016/j.marpolbul.2011.03.041

644 Larsson, A.I., van Oevelen, D., Purser, A., Thomsen, L., 2013. Tolerance to long-term 645 exposure of suspended benthic sediments and drill cuttings in the cold-water coral Lophelia 646 pertusa. $\quad$ Marine $\quad$ Pollution $\quad$ Bulletin $\quad 70, \quad 188$. 
https://doi.org/10.1016/j.marpolbul.2013.02.033

648 Lartaud, F., Meistertzheim, A.L., Peru, E., Le Bris, N., 2017. In situ growth experiments of 649 reef-building cold-water corals: The good, the bad and the ugly. Deep Sea Research Part I: 650 Oceanographic Research Papers 121, 70-78. https://doi.org/10.1016/j.dsr.2017.01.004

651 Lartaud, F., Mouchi, V., Chapron, L., Meistertzheim, A.-L., Le Bris, N., in press. Growth 652 patterns of Mediterranean calcifying cold-water corals, in: Past, Present and Future of 653 Mediterranean Cold-water Corals, Springer "Coral Reefs of the World."

654 Lartaud, F., Pareige, S., de Rafelis, M., Feuillassier, L., Bideau, M., Peru, E., De la Vega, E., 655 Nedoncelle, K., Romans, P., Le Bris, N., 2014a. Temporal changes in the growth of two 656 Mediterranean cold-water coral species, in situ and in aquaria. Deep Sea Research Part II: 657 Topical Studies in Oceanography 99, 64-70. https://doi.org/10.1016/j.dsr2.2013.06.024 658 Lartaud, F., Pareige, S., de Rafelis, M., Feuillassier, L., Bideau, M., Peru, E., De la Vega, E., 659 Nedoncelle, K., Romans, P., Le Bris, N., 2014b. Temporal changes in the growth of two 660 Mediterranean cold-water coral species, in situ and in aquaria. Deep Sea Research Part II: 661 Topical Studies in Oceanography 99, 64-70. https://doi.org/10.1016/j.dsr2.2013.06.024

662 Levin, L.A., Le Bris, N., 2015. The deep ocean under climate change. Science 350, 766-768. 663 Lunden, J.J., McNicholl, C.G., Sears, C.R., Morrison, C.L., Cordes, E.E., 2014. Acute 664 survivorship of the deep-sea coral Lophelia pertusa from the Gulf of Mexico under 665 acidification, warming, and deoxygenation. Frontiers in Marine Science 1. 666 https://doi.org/10.3389/fmars.2014.00078

667 Maier, C., Watremez, P., Taviani, M., Weinbauer, M.G., Gattuso, J.P., 2012. Calcification 668 rates and the effect of ocean acidification on Mediterranean cold-water corals. Proceedings of 669 the Royal Society B: Biological Sciences 279, 1716-1723. 670 https://doi.org/10.1098/rspb.2011.1763

671 Meistertzheim, A-L., Lartaud, F., Arnaud-Haond, S., Kalenitchenko, D., Bessalam, M., Le 
672 Bris, N., Galand, P.E., 2016. Patterns of bacteria-host associations suggest different 673 ecological strategies between two reef building cold-water coral species. Deep Sea Research 674 Part I: Oceanographic Research Papers 114, 12-22. https://doi.org/10.1016/j.dsr.2016.04.013 675 Mortensen, P.B., 2001. Aquarium observations on the deep-water coral Lophelia pertusa (L., 676 1758) (scleractinia) and selected associated invertebrates. Ophelia 54, 83-104. 677 https://doi.org/10.1080/00785236.2001.10409457

678 Musco, L., Vega Fernández, T., Caroselli, E., Roberts, J.M., Badalamenti, F., 2018. 679 Protocooperation among small polyps allows the coral Astroides calycularis to prey on large 680 jellyfish. Ecology 99, 2400-2401. https://doi.org/10.1002/ecy.2413

681 Naumann, M.S., Orejas, C., Ferrier-Pagès, C., 2014. Species-specific physiological response 682 by the cold-water corals Lophelia pertusa and Madrepora oculata to variations within their 683 natural temperature range. Deep Sea Research Part II: Topical Studies in Oceanography 99, 684 36-41. https://doi.org/10.1016/j.dsr2.2013.05.025

685 Naumann, M.S., Orejas, C., Wild, C., Ferrier-Pages, C., 2011. First evidence for zooplankton 686 feeding sustaining key physiological processes in a scleractinian cold-water coral. Journal of 687 Experimental Biology 214, 3570-3576. https://doi.org/10.1242/jeb.061390

688 Oevelen, D. van, Duineveld, G., Lavaleye, M., Mienis, F., Soetaert, K., Heip, C.H., 2009. The 689 cold-water coral community as hotspot of carbon cycling on continental margins: A food-web 690 analysis from Rockall Bank (northeast Atlantic). Limnology and Oceanography 54, 18296911844.

692 Orejas, C., Ferrier-Pagès, C., Reynaud, S., Tsounis, G., Allemand, D., Gili, J.M., 2011. 693 Experimental comparison of skeletal growth rates in the cold-water coral Madrepora oculata 694 Linnaeus, 1758 and three tropical scleractinian corals. Journal of Experimental Marine 695 Biology and Ecology 405, 1-5. https://doi.org/10.1016/j.jembe.2011.05.008

696 Orejas, C., Gori, A., Rad-Menéndez, C., Last, K.S., Davies, A.J., Beveridge, C.M., Sadd, D., 
697 Kiriakoulakis, K., Witte, U., Roberts, J.M., 2016. The effect of flow speed and food size on

698 the capture efficiency and feeding behaviour of the cold-water coral Lophelia pertusa. Journal 699 of Experimental Marine Biology and Ecology 481, 34-40. 700 https://doi.org/10.1016/j.jembe.2016.04.002

701 Palanques, A., Durrieu de Madron, X., Puig, P., Fabres, J., Guillén, J., Calafat, A., Canals, M., 702 Heussner, S., Bonnin, J., 2006. Suspended sediment fluxes and transport processes in the Gulf 703 of Lions submarine canyons. The role of storms and dense water cascading. Marine Geology 704 234, 43-61. https://doi.org/10.1016/j.margeo.2006.09.002

705 Puig, P., Madron, X.D. de, Salat, J., Schroeder, K., Martín, J., Karageorgis, A.P., Palanques, 706 A., Roullier, F., Lopez-Jurado, J.L., Emelianov, M., Moutin, T., Houpert, L., 2013. Thick 707 bottom nepheloid layers in the western Mediterranean generated by deep dense shelf water 708 cascading. Progress in Oceanography 1-23. 709 https://doi.org/10.1016/j.pocean.2012.10.003

710 Purser, A., Larsson, A.I., Thomsen, L., van Oevelen, D., 2010. The influence of flow velocity 711 and food concentration on Lophelia pertusa (Scleractinia) zooplankton capture rates. Journal 712 of Experimental Marine Biology and Ecology 395, 55-62. 713 https://doi.org/10.1016/j.jembe.2010.08.013

714 Pusceddu, A., Mea, M., Canals, M., Heussner, S., Durrieu de Madron, X., Sanchez-Vidal, A., 715 Bianchelli, S., Corinaldesi, C., Dell'Anno, A., Thomsen, L., Danovaro, R., 2013. Major 716 consequences of an intense dense shelf water cascading event on deep-sea benthic trophic 717 conditions and meiofaunal biodiversity. Biogeosciences 10, 2659-2670. 718 https://doi.org/10.5194/bg-10-2659-2013

719 Roberts J. Murray, Wheeler Andrew J., Freiwald Andre', 2006. Reefs of the Deep: The 720 Biology and Geology of Cold-Water Coral Ecosystems. Science, London.

721 Roberts, J.M. (Ed.), 2009. Cold-water corals: the biology and geology of deep-sea coral 
habitats. Cambridge University Press, Cambridge, UK; New York.

723 Roberts, J.M., Anderson, R.M., 2002. A new laboratory method for monitoring deep-water 724 coral polyp behaviour. Hydrobiologia 471, 143-148.

725 Rogers, A.D., 1999. The Biology of Lophelia pertusa (LINNAEUS 1758) and Other Deep726 Water Reef-Forming Corals and Impacts from Human Activities. International Review of 727 Hydrobiology 84, 315-406.

728 Sabatier, P., Reyss, J.-L., Hall-Spencer, J.M., Colin, C., Frank, N., Tisnérat-Laborde, N., 729 Bordier, L., Douville, E., 2012. ${ }^{210} \mathrm{~Pb}-{ }^{226} \mathrm{Ra}$ chronology reveals rapid growth rate of 730 Madrepora oculata and Lophelia pertusa on world's largest cold-water coral reef. 731 Biogeosciences 9, 1253-1265. https://doi.org/10.5194/bg-9-1253-2012

732 Somot, S., Sevault, F., Déqué, M., 2006. Transient climate change scenario simulation of the 733 Mediterranean Sea for the twenty-first century using a high-resolution ocean circulation 734 model. Climate Dynamics 27, 851-879.

735 Strömberg, S.M., Lundälv, T., Goreau, T.J., 2010. Suitability of mineral accretion as a 736 rehabilitation method for cold-water coral reefs. Journal of Experimental Marine Biology and 737 Ecology 395, 153-161. https://doi.org/10.1016/j.jembe.2010.08.028

738 Thiem, Ø., Ravagnan, E., Fosså, J.H., Berntsen, J., 2006. Food supply mechanisms for cold739 water corals along a continental shelf edge. Journal of Marine Systems 60, 207-219. 740 https://doi.org/10.1016/j.jmarsys.2005.12.004

741 Tsounis, G., Orejas, C., Reynaud, S., Gili, J.-M., Allemand, D., Ferrier-Pagès, C., 2010. Prey742 capture rates in four Mediterranean cold water corals. Marine Ecology Progress Series 398, $743 \quad 149-155$.

744 Ulses, C., Estournel, C., Bonnin, J., Durrieu de Madron, X., Marsaleix, P., 2008a. Impact of 745 storms and dense water cascading on shelf-slope exchanges in the Gulf of Lion (NW 746 Mediterranean). Journal of Geophysical Research 113. https://doi.org/10.1029/2006JC003795 
747 Ulses, C., Estournel, C., Durrieu de Madron, X., Palanques, A., 2008b. Suspended sediment

748 transport in the Gulf of Lions (NW Mediterranean): Impact of extreme storms and floods.

749 Continental Shelf Research 28, 2048-2070. https://doi.org/10.1016/j.csr.2008.01.015

750 Ulses, C., Estournel, C., Puig, P., Durrieu de Madron, X., Marsaleix, P., 2008c. Dense shelf

751 water cascading in the northwestern Mediterranean during the cold winter 2005:

752 Quantification of the export through the Gulf of Lion and the Catalan margin: Cascading in

753 the Mediterranean sea. Geophysical Research Letters 35, n/a-n/a.

754 https://doi.org/10.1029/2008GL033257

755 Vad, J., Orejas, C., Moreno-Navas, J., Findlay, H.S., Roberts, J.M., 2017. Assessing the living

756 and dead proportions of cold-water coral colonies: implications for deep-water Marine

757 Protected Area monitoring in a changing ocean. PeerJ 5, e3705.

758 https://doi.org/10.7717/peerj.3705

759 Waller, R.G., Tyler, P.A., 2005. The reproductive biology of two deep-water, reef-building

760 scleractinians from the NE Atlantic Ocean. Coral Reefs 24, 514-522.

761 https://doi.org/10.1007/s00338-005-0501-7

762 Wilson, J.B., 1979. 'Patch' development of the deep-water coral Lophelia Pertusa (L.) on

763 Rockall Bank. Journal of the Marine Biological Association of the United Kingdom 59, 165.

764 https://doi.org/10.1017/S0025315400046257

765

766 
767 Table 1: Characteristics of the transplant units used for each time period for L. pertusa

768 and M. oculata. The mean \pm SD is shown for the polyp mortality.

769

\begin{tabular}{|c|c|c|c|c|c|c|c|c|}
\hline Species & Time period & $\begin{array}{c}\text { Transplant } \\
\text { unit }\end{array}$ & $\begin{array}{c}\text { Number of } \\
\text { colonies }\end{array}$ & $\begin{array}{l}\text { Number of } \\
\text { replicates }\end{array}$ & $\begin{array}{c}\text { Initial number } \\
\text { of polyps }\end{array}$ & $\begin{array}{l}\text { Number of } \\
\text { new polyps }\end{array}$ & $\begin{array}{c}\text { Breakage } \\
(\%)\end{array}$ & $\begin{array}{c}\text { Mortality } \\
(\%)\end{array}$ \\
\hline \multirow[t]{8}{*}{ L. pertusa } & Nov2010-Sep2011 & NS & 2 & 4 & 12 & 6 & 8 & $0 \pm 0$ \\
\hline & Sep2011-Jul2012 & NS & 2 & 6 & 20 & 9 & 5 & $18 \pm 36$ \\
\hline & Jul2013-Oct2014 & NS & 1 & 4 & 13 & 0 & 8 & $100 \pm 0$ \\
\hline & & BS & 2 & 2 & 20 & 1 & 13 & $100 \pm 0$ \\
\hline & Jun2015-Jun2016 & NS & 2 & 7 & 31 & 6 & 9 & $87 \pm 34$ \\
\hline & & BS & 1 & 3 & 61 & 13 & 24 & $34 \pm 57$ \\
\hline & Jun2016-Jun2017 & BS & 2 & 5 & 96 & 66 & 3 & $15 \pm 12$ \\
\hline & Jun2017-May2018 & BS & 2 & 5 & 130 & 54 & 1 & $17 \pm 27$ \\
\hline \multirow[t]{8}{*}{ M. oculata } & Nov2010-Sep2011 & NS & 2 & 5 & 38 & 16 & 0 & $0 \pm 0$ \\
\hline & Sep2011-Jul2012 & NS & 2 & 7 & 76 & 11 & 0 & $48 \pm 43$ \\
\hline & Jul2013-Oct2014 & NS & 3 & 12 & 118 & 7 & 5 & $96 \pm 13$ \\
\hline & & BS & 3 & 6 & 141 & 10 & 51 & $100 \pm 0$ \\
\hline & Jun2015-Jun2016 & NS & 1 & 8 & 81 & 2 & 10 & $67 \pm 38$ \\
\hline & & BS & 1 & 2 & 39 & 0 & 34 & $86 \pm 19$ \\
\hline & Jun2016-Jun2017 & BS & 1 & 5 & 229 & 63 & 6 & $23 \pm 12$ \\
\hline & Jun2017-May2018 & BS & 1 & 6 & 226 & 9 & 0 & $70 \pm 40$ \\
\hline
\end{tabular}



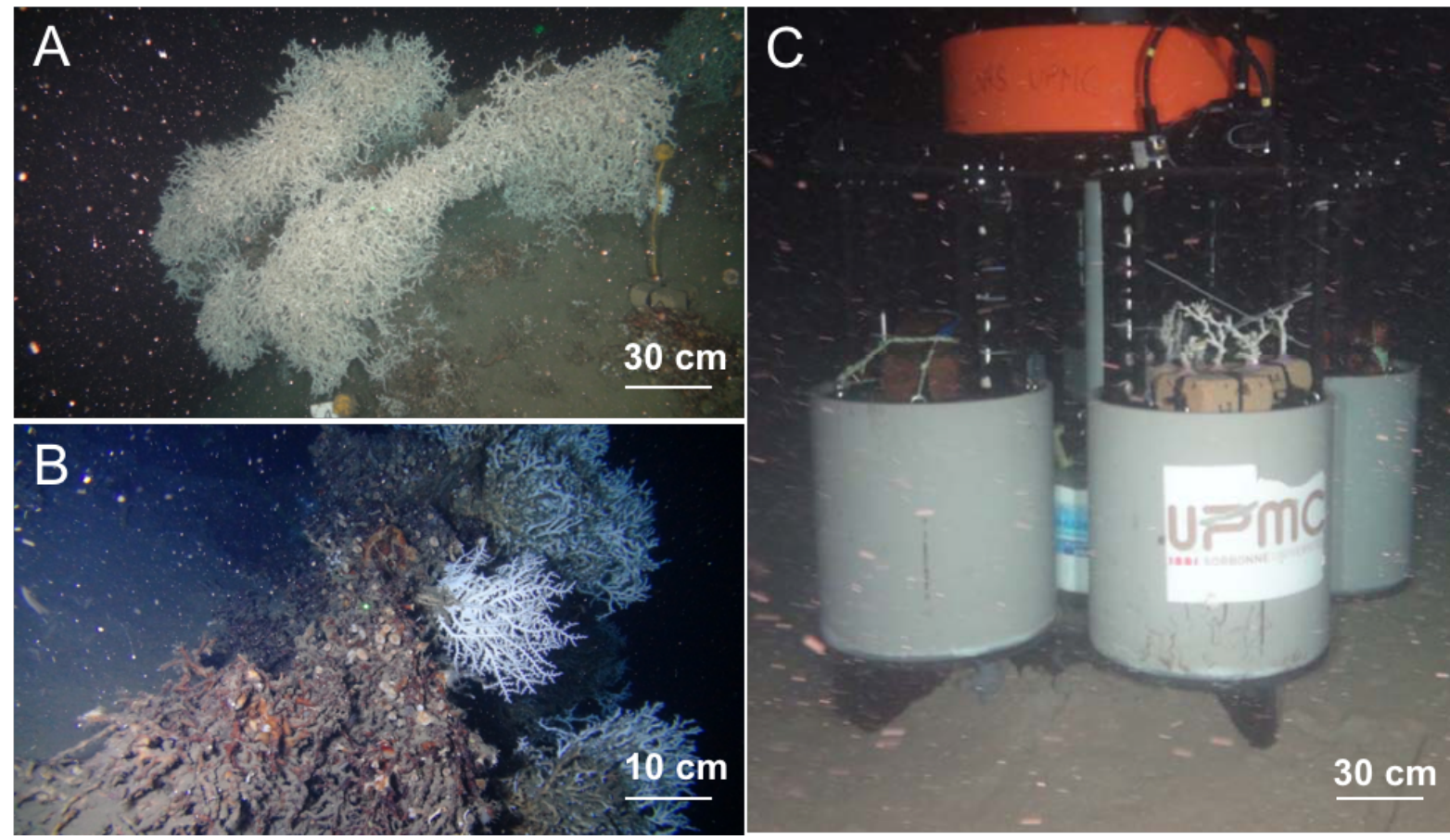

Figure 1: (A-B) Cold-water coral reefs with (A) Lophelia pertusa and (B) Madrepora

776 deployed on transplant units fixed to the deep-sea experimentation platform. 


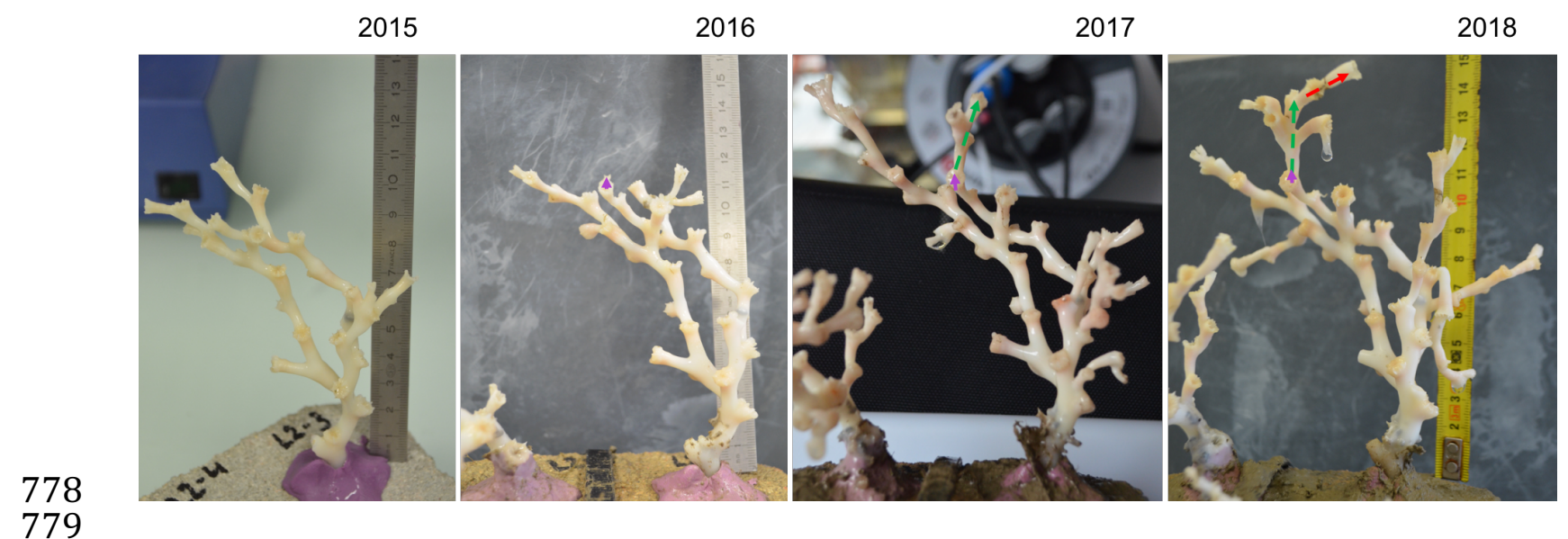

780 Figure 2: The pictures represent the same replicate of L. pertusa during four years (in

781 purple, the first linear extension during 2015-2016, the second in green during 2016-

$782 \quad 2017$ and the third in red during 2017-2018).

783 


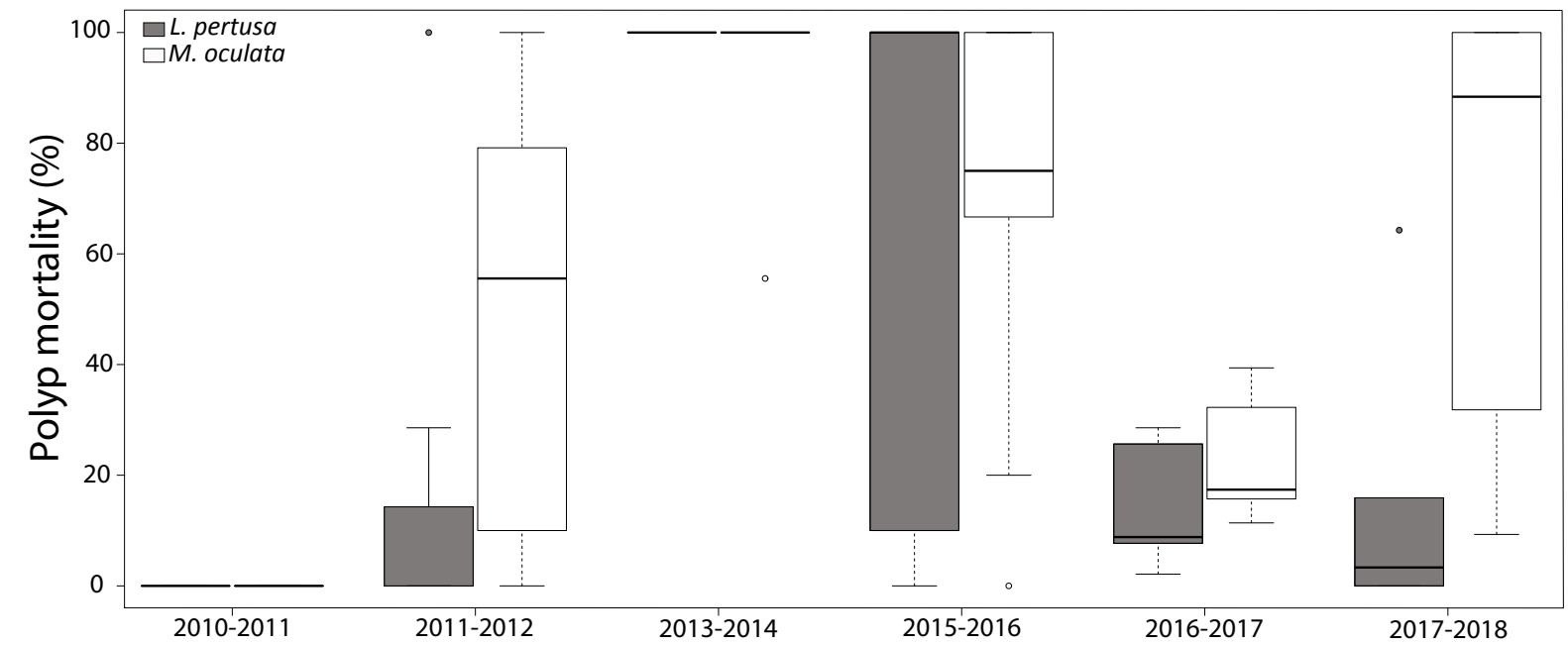

Figure 3: Polyp mortality of L. pertusa (grey) and M. oculata (white bars) between 2010 and 2018. All the values represented the median, quartiles and extrema. 


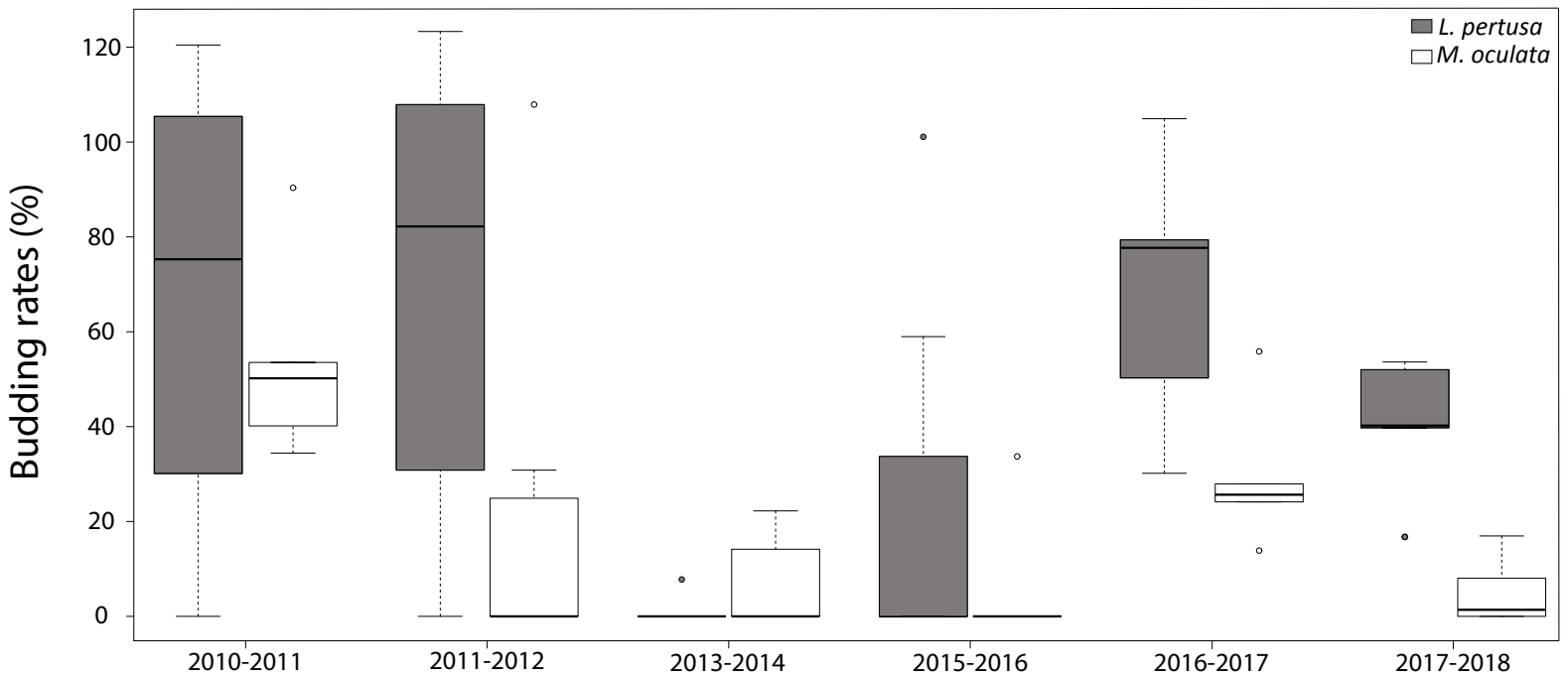

Figure 4: Budding rates (\%) of L. pertusa (grey) and M. oculata (white bars) between 7932010 and 2018. All the values represented the median, quartiles and extrema. 


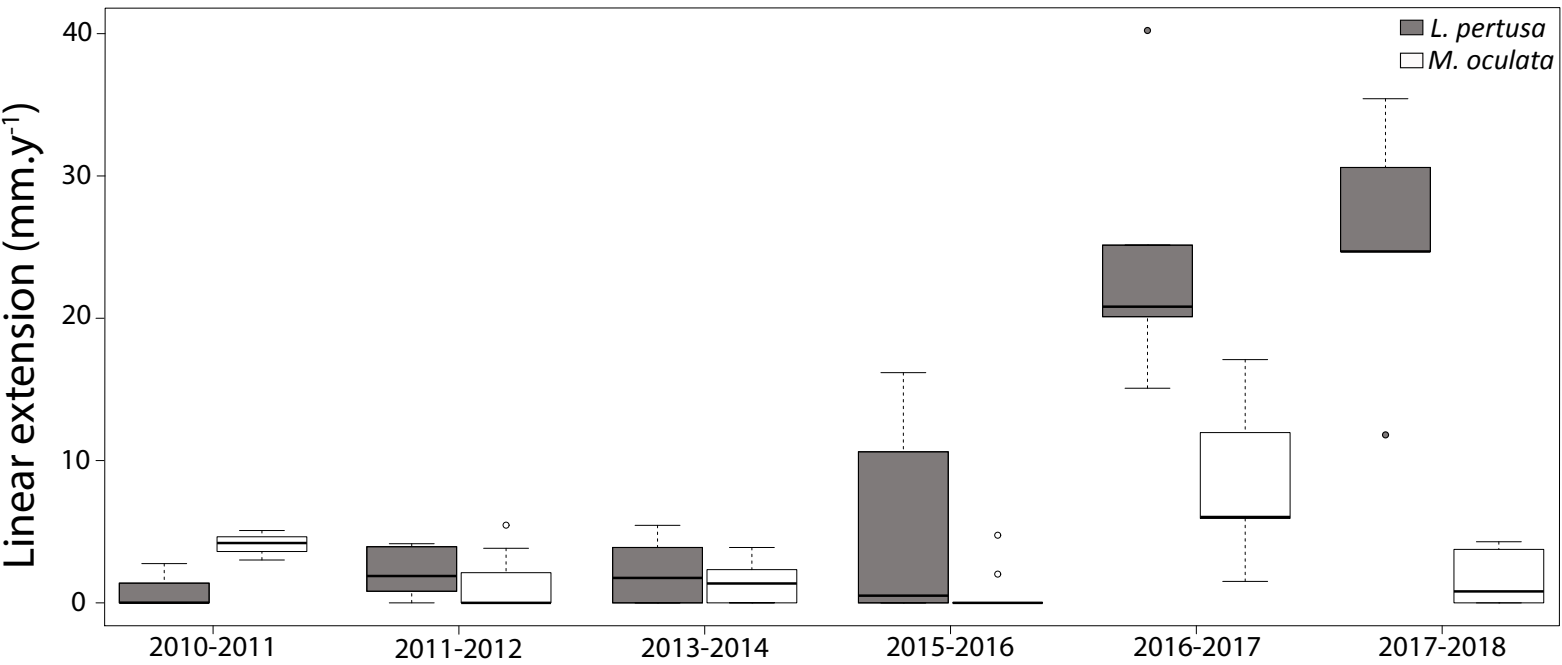

798 Figure 5: Linear extension (mm.y $\mathrm{y}^{-1}$ ) of L. pertusa (grey) and M. oculata (white bars)

799 between 2010 and 2018. All the values represented the median, quartiles and extrema.

800 

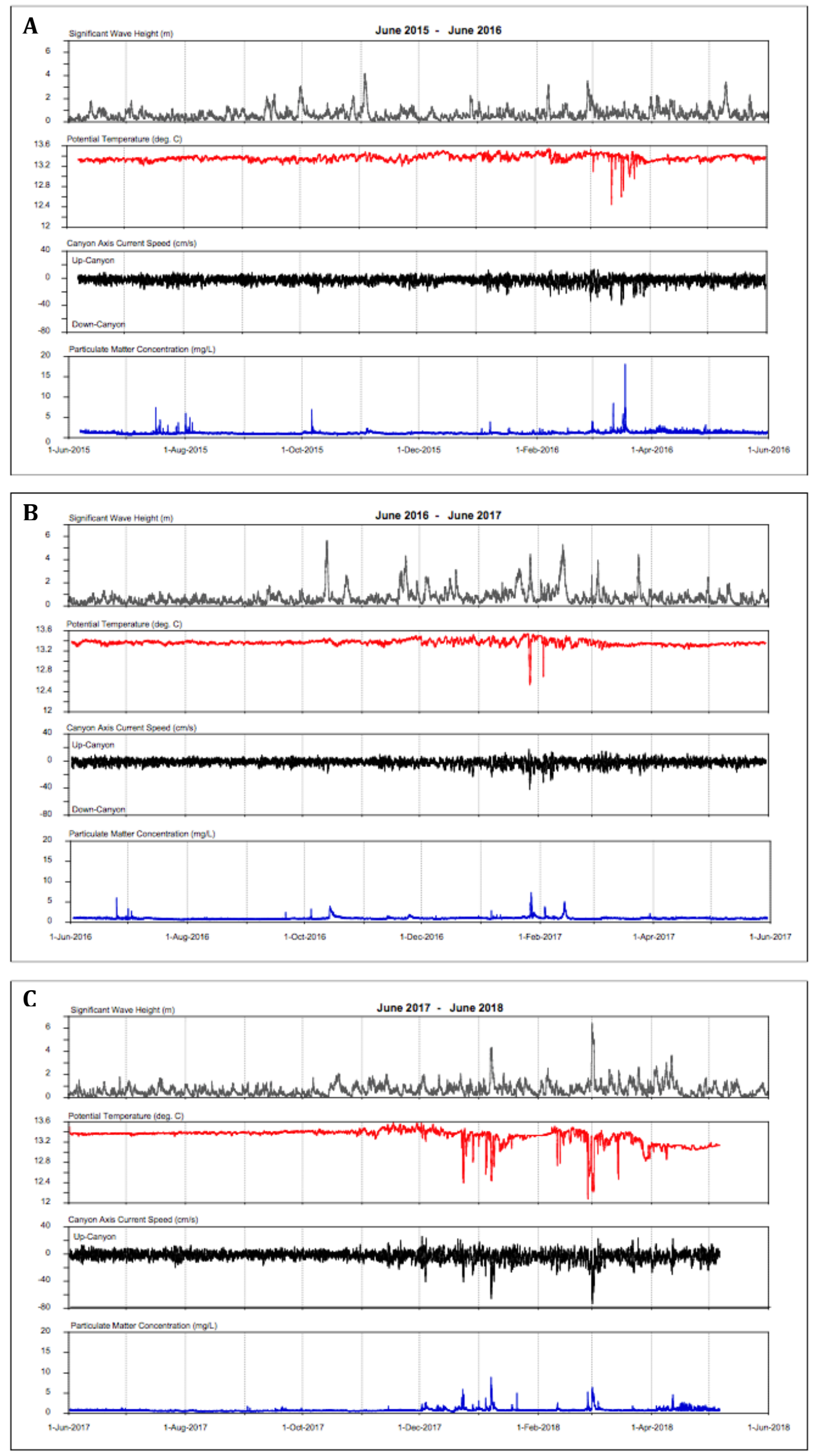
802

803 Figure 6: Time series of significant wave height at the Leucate site, near-bottom 804 temperature, near-bottom current speed component along the canyon axis, and near805 bottom suspended particle matter concentration, at $530 \mathrm{~m}$ depth in the Lacaze-Duthiers 806 canyon for the (A) 2015-2016, (B) 2016-2017 and (C) 2017-2018.

807 